\title{
Ambient Air Quality \& Noise Level Monitoring of Different Areas of Lahore (Pakistan) and Its Health Impacts
}

\author{
Almas Hamid ${ }^{1 *}$, Sana Akhtar1, Syeda Aleena Atique ${ }^{1}$, Zilley Huma1, \\ Syed Ghulam Mohay Uddin ${ }^{2}$, Sidra Asghar ${ }^{1}$ \\ ${ }^{1}$ Department of Environmental Sciences, Kinnaird College for Women, Lahore, Pakistan \\ ${ }^{2}$ GIS analyst WWF, Pakistan
}

Received: 3 October 2017

Accepted: 2 January 2018

\begin{abstract}
The present study assesses ambient air quality in terms of the gaseous pollutants sulfur dioxide $\left(\mathrm{SO}_{2}\right)$, nitrogen oxide (NO), carbon monoxide (CO), total suspended particulates (TSP), and noise levels at four busy road intersections, along with their associated residential areas in Lahore, Pakistan. A dense transport system and extensive industry are major causes of serious damage to the urban environment and human health in Lahore. Air and noise monitoring was conducted in the mornings, afternoons, and evenings for 3 consecutive days of a month for a period of 8 months. Results showed that average concentrations of $\mathrm{SO}_{2}$ at study sites throughout the monitoring cycle were in the range of $0.005 \mathrm{ppm}$ to $0.062 \mathrm{ppm}$, while average NO concentrations varied between $0.5 \mathrm{ppm}$ and $1.34 \mathrm{ppm}$. CO concentrations were recorded between $9.5 \mathrm{ppm}$ and $16.75 \mathrm{ppm}$, whereas the average concentrations of TSP ranged $622-1046 \mu \mathrm{g} / \mathrm{m}^{3}$. The average noise levels ranged from $67.2 \mathrm{~dB}$ to $120.1 \mathrm{~dB}$. Moreover, a questionnaire survey carried out to examine the health impacts of pollutants on potential receivers such as workers, laborers, shop-keepers, nearby residents, and traffic wardens showed the existence of various diseases among respondents due to deteriorating air quality and elevated noise levels.
\end{abstract}

Keywords: air quality, noise pollution, nitrogen oxide, sulfur dioxide, Lahore, health effects, GIS

\section{Introduction}

The problem of escalating air pollution in many developing countries is associated with overpopulation and increasing industrialization. Air pollution at the regional level in many of these developing nations has been attributed to the use of non-renewable fuels such

*e-mail: almas209@yahoo.com as diesel and biomass [1]. According to a World Health Organization (WHO) estimate, around 3.7 million deaths in 2012 were linked to ambient air pollution [2], with $88 \%$ occurring in low- and middle-income countries. Particulate matter $\left(\mathrm{PM}_{10}\right.$ and $\left.\mathrm{PM}_{2.5}\right)$ is allegedly responsible for cardiovascular and respiratory diseases and cancer [3-5]. Air quality a sssessment in the Asian region shows that concentrations of air pollutants in highincome countries also usually exceed WHO guidelines and ambient air quality standards [6-7]. 
Lahore, the second largest city of Pakistan, with a population of approximately 10 million people, boasts of a dense transport system and extensive industrial establishments that are major causes of serious damage to the urban environment and human health [8]. Vehicular emissions are accountable for air pollutants, including $\mathrm{CO}$, NO, hydrocarbons, and particulate matter (PM). According to Punjab Development Statistics, the total number of registered vehicles in Lahore has increased tremendously, from 39,205 in 1974 to $1,464,344$ in 2006 and up to $3,991,517$ in June 2014 [9]. In 2015 the number stood at $9,482,000$, which is expected to grow to $13,068,000$ by 2025 [10].

Ambient air quality monitoring of Islamabad, Pakistan showed annual average concentrations of $\mathrm{PM}_{2.5}$ and nitric oxide as $45-95 \mu \mathrm{gm}^{-3}$ and $41-120 \mu \mathrm{gm}^{-3}$, respectively, which are higher than Pakistan's National Environmental Quality Standards [11]. The highest levels of measured TSP, $\mathrm{PM}_{10}, \mathrm{SO}_{2}, \mathrm{NO}_{x}$, and ozone have been observed in Lahore [12]. Waheed et al. also reported exceedingly elevated levels of SPM $\left(1,128-1,870 \mu \mathrm{g} / \mathrm{m}^{3}\right)$ in Lahore $[1,13]$. Other monitoring studies show the deteriorating ambient air quality of major cities, including Lahore [14-17], with increasing fog incidents associated with detrimental economic and health impacts [18].

Noise pollution is also a direct consequence of increased vehicular volume, and Lahore is no exception. Studies indicate that the populations of major cities of Pakistan are exposed to higher noise levels, with drivers at a greater risk as reportedly $65 \%$ of drivers in Lahore suffer from noise-induced hearing loss [19]. Besides auditory effects, noise pollution is related to other adverse impacts ranging from simple annoyance, concentration loss, and stress to more serious ailments like mental health deterioration and cardiovascular diseases [20-24]. According to WHO statistics, traffic noise results in an estimated one million health life years in the European Union and other western countries [20].

In addition to these already existing burdens, the construction of development projects underway at Lahore such as the rapid mass transit Orange Line and signal-free road projects have worsened the situation. The present study was conducted to measure the existing levels of $\mathrm{SO}_{2}, \mathrm{NO}, \mathrm{CO}$, TSP, and noise levels at major road intersections and adjoining residential areas of Lahore and to assess the adverse health implications of this increasing air and noise pollution.

\section{Materials and Methods}

\section{Study Site}

Eight areas comprising Yateem Khana Intersection (YKI), Karim Block Intersection (KBI), Qartaba Intersection (QI), and Shadman Intersection (SI) with their respective adjoining residential areas (designated as YKR, KBR, QR, and SR) were selected for air monitoring (Fig. 1). The initial survey of the study areas was conducted to identify suitable monitoring points for air and noise monitoring based on factors such as traffic load and proximate residential areas. The distance between monitoring points at YKI and YKR is $700 \mathrm{~m}$, while the respective distance of KBI from KBR is $650 \mathrm{~m}$, that of QI and QR is $400 \mathrm{~m}$, and of SI and SR is $720 \mathrm{~m}$.

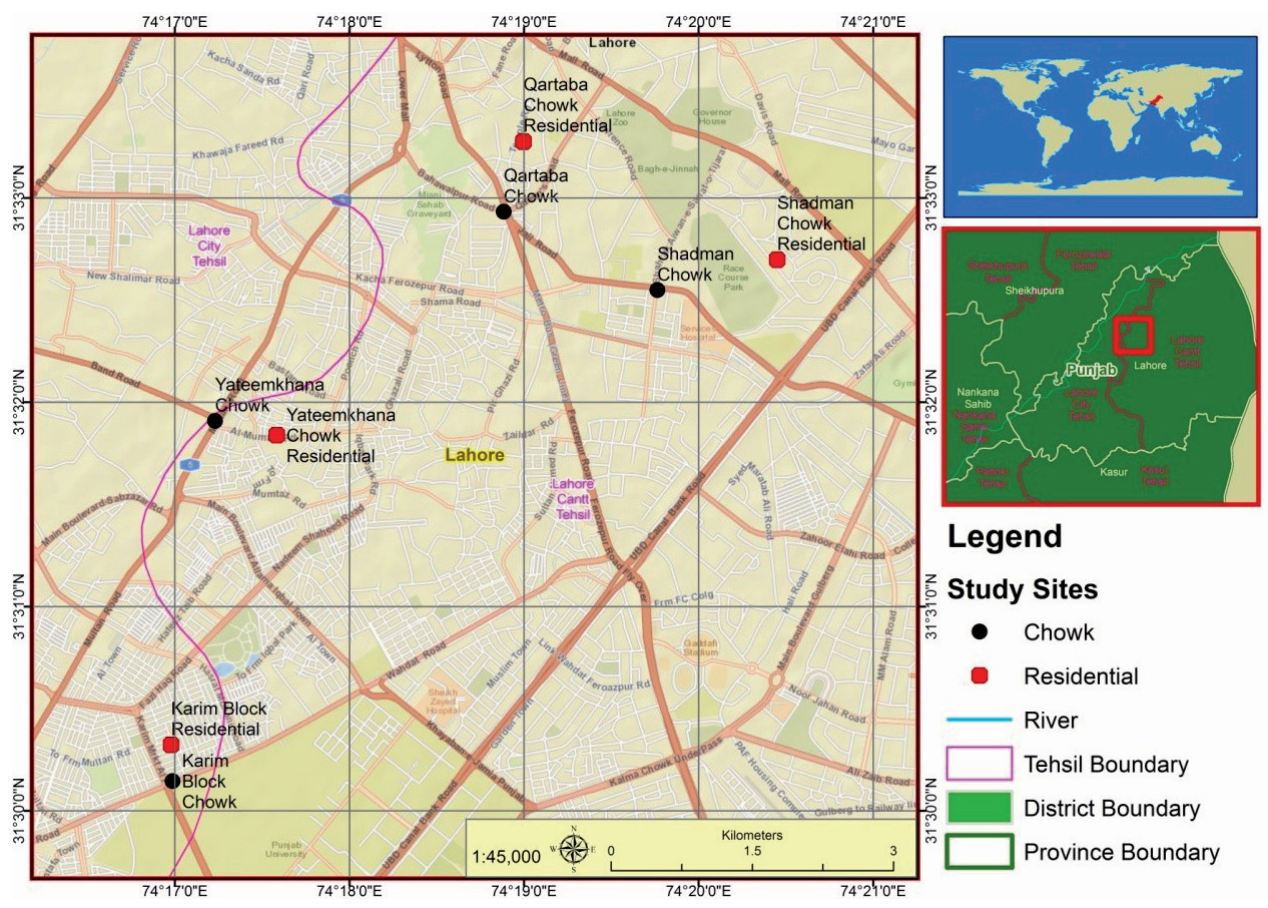

Fig. 1. Study area map showing sampling locations. 


\section{Air, Noise, and Meteorological Monitoring}

The parameters monitored include TSP, $\mathrm{SO}_{2}, \mathrm{NO}$, $\mathrm{CO}$, and Noise. Daily monitoring was carried out for 3 consecutive days of each month for a duration of 8 months from July 2015 to February 2016, thrice a day: morning (08:00-10:00), afternoon (13:00-15:00) and evening (18:00-20:00). MX6 iBrid air analyzer was used for gaseous monitoring, while TSP was monitored using a Micro Dust Pro Casella Cell/CEL-712. A digital sound level meter/OS-11 was employed to monitor noise levels.

\section{Designing Health-Based Questionnaire and Field Survey}

A questionnaire was designed and administered to 50 respondents from each area in order to assess the health status and the perceived effects of air and noise pollution on potential receivers such as workers, laborers, shopkeepers, residents, and traffic wardens at and around the monitoring sites. A specific section of the questionnaire was designed and targeted to the traffic wardens on duty at the commercial areas/road intersections and traffic signals.

\section{GIS Mapping Methodology}

Using ArcMap 10.1, four layers were developed to show the prevalence of $\mathrm{CO}, \mathrm{SO}_{x}, \mathrm{NO}_{x}$, TSP, and noise levels within the area of interest (AOI). These layers were developed by adopting the nearest neighbor $(\mathrm{NN})$ algorithm through interpolation techniques. Areas with pollutants above NAAQS limits were mapped in each layer using the point feature. Points where these pollutants reached threat levels with regard to health impacts were highlighted. Each of the layers developed were stacked to create a composite layer that resulted in a single layer showing the hot spots where the said pollutants attained threateningly high levels within the city.

\section{Results and Discussion}

\section{Air and Noise Quality Assessment}

Results of ambient air quality monitoring showed a direct relationship between traffic density and concentration of pollutants. Traffic volume passing through these intersections indicated a direct relationship of TSP and noise pollution with the number and type of vehicles, i.e., cars, buses, vans, trucks, motor cars, motor bikes, and rickshaws. TSP and noise levels as a result of traffic volume were also found to be directly related to the time of day. The traffic volume was observed to be high in late afternoons until late evenings (16:00-20:00) owing to multiple reasons, which include but are not limited to the off time of offices, recreational activities

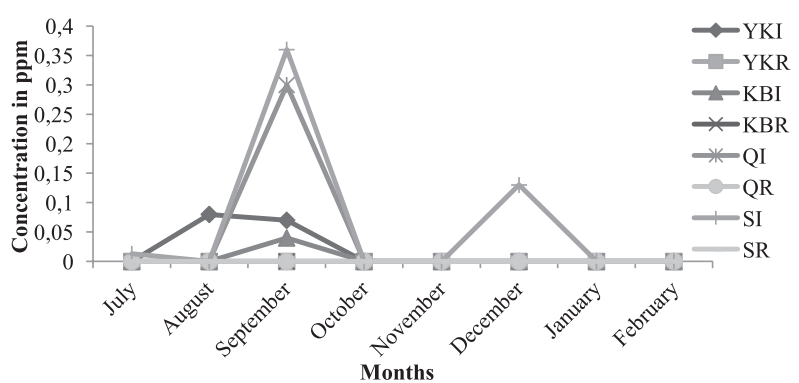

Fig. 2. Monthly average concentrations of $\mathrm{SO}_{2}$ at all monitoring sites.

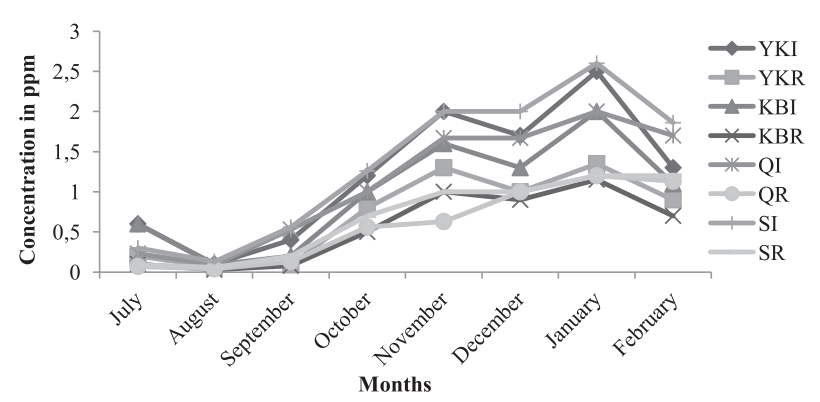

Fig. 3. Monthly average concentrations of NO at all monitoring sites.

of people, and also culture of scheduling most of the occasions/events at late evenings in Lahore.

Monthly average concentrations of $\mathrm{SO}_{2}$ (Fig. 2) show the highest $\mathrm{SO}_{2}$ concentration measured at SI $(0.36 \mathrm{ppm})$ during September 2015. The average concentrations of $\mathrm{SO}_{2}$ throughout the monitoring cycle were $0.019 \pm 0.03482,0.005 \pm 0.01414,0.04 \pm 0.03536$ and $0.062 \pm 0.07954 \mathrm{ppm}$ at YKI, KBI, QI, and SI, respectively. The concentrations, except at SI, were within Pakistan NAAQS, i.e., 0.045 ppm [16], but higher than the WHO standard for $24 \mathrm{hr}$ average $(0.00764 \mathrm{ppm})$. An earlier study reported $\mathrm{SO}_{2}$ levels in Lahore in the range $0.02-0.05 \mathrm{ppm}$ [12], whereas lately mean $\mathrm{SO}_{2}$ concentration (24 hours) at Qartaba (QI) and Shadman Chowks (SI) were measured as $0.0714 \mathrm{ppm}$ and $0.054 \mathrm{ppm}$, respectively [25], which are higher than those measured during the present study.

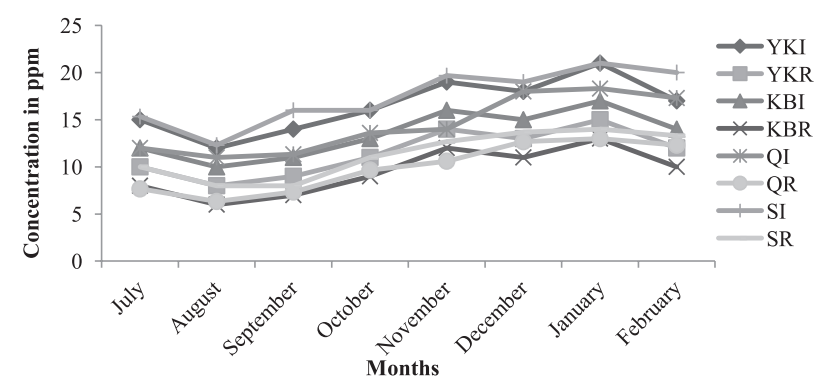

Fig. 4. Average monthly Concentrations of $\mathrm{CO}$ at all monitoring sites. 


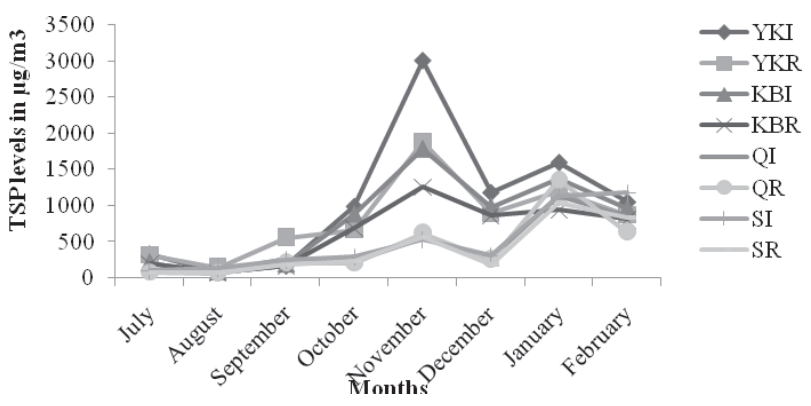

Fig. 5. Average monthly concentrations of TSP at all monitoring sites.

Monthly average NO concentrations at all sites (as depicted in Fig. 3) show that the highest average NO concentration was measured at SI $(2.6 \mathrm{ppm})$ in January 2016, while the lowest was recorded at KBR
(0.03 ppm) in August 2015. While the average NO concentrations throughout the monitoring cycle were recorded to be $1.22 \pm 0.82765,0.7 \pm 0.52820,1 \pm 0.66403$, $0.5 \pm 0.44775,1.12 \pm 0.08741,0.59 \pm 0.37201,1.34 \pm 0.52636$, and $0.69 \pm 0.53456 \mathrm{ppm}$ at YKI, YKR, KBI, KBR, QI, QR, SI, and SR, respectively, levels alarmingly exceeding the NAAQS (0.03 ppm). According to an earlier study in Lahore, the concentration of NO was $0.22 \mathrm{ppm}$, which was higher than standards [17].

Monthly average concentrations of $\mathrm{CO}$ at all sites (Fig. 4) showed the highest average $\mathrm{CO}$ level (21 ppm) in January 2016 at YKI and SI, while the lowest was measured during August 2015 at KBR (6 ppm). During the entire monitoring duration, the average $\mathrm{CO}$ concentrations were recorded as $16.5 \pm 2.878,11.5 \pm 2.449$,

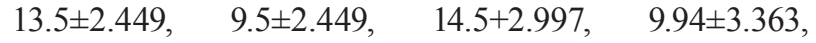
$16.57 \pm 3.444$, and $11.33+3.405 \mathrm{ppm}$ at YKI, YKR, KBI, KBR, QI, QR, SI, and SR, respectively. These levels

Table 1. Percentage of reported health problems by respondents.

\begin{tabular}{|c|c|c|c|c|c|c|}
\hline $\begin{array}{l}\text { Sr. } \\
\text { No. }\end{array}$ & Reported Symptoms & YKR & KBR & QR & SR & $\begin{array}{l}\text { Total affected } \\
\text { Wardens }\end{array}$ \\
\hline 1 & $\begin{array}{c}\text { Respiratory diseases } \\
\text { (Coughing and wheezing, congestion, shortness of breath, increase in } \\
\text { asthma and lung cancer, etc.) }\end{array}$ & $26 \%$ & $22 \%$ & $20 \%$ & $25 \%$ & $21 \%$ \\
\hline 2 & $\begin{array}{c}\text { Skin Problems } \\
\text { (Aging, pimples, allergies, etc.) }\end{array}$ & $8 \%$ & $10 \%$ & $5 \%$ & $9 \%$ & $8 \%$ \\
\hline 3 & $\begin{array}{l}\text { Cardiovascular Problems } \\
\text { (Heart attacks, abnormal heart beat, strokes, hardening of arteries, etc.) }\end{array}$ & $5 \%$ & $5 \%$ & $6 \%$ & $3 \%$ & $10 \%$ \\
\hline 4 & Hearing Impairment & $6 \%$ & $4 \%$ & $4 \%$ & $8 \%$ & $13 \%$ \\
\hline \multirow{16}{*}{5} & \multicolumn{5}{|l|}{ Others } & \\
\hline & - Headaches & $30 \%$ & $26 \%$ & - & - & $18 \%$ \\
\hline & - Nausea & $8 \%$ & $7 \%$ & $5 \%$ & $7 \%$ & $18 \%$ \\
\hline & - Dizziness & $8 \%$ & $4 \%$ & $7 \%$ & $8 \%$ & $9 \%$ \\
\hline & - Irritation of eyes, nose and throat & $16 \%$ & $13 \%$ & $21 \%$ & $21 \%$ & $17 \%$ \\
\hline & - Insomnia & $5 \%$ & $6 \%$ & $4 \%$ & $5 \%$ & $2 \%$ \\
\hline & - Depression & $16 \%$ & $15 \%$ & $4 \%$ & $7 \%$ & $5 \%$ \\
\hline & - Stress & $10 \%$ & $21 \%$ & $8 \%$ & $10 \%$ & $10 \%$ \\
\hline & - Public Conflicts & $3 \%$ & $1 \%$ & $5 \%$ & $8 \%$ & $7 \%$ \\
\hline & - Irritation and Annoyance & $13 \%$ & $19 \%$ & $5 \%$ & $8 \%$ & $9 \%$ \\
\hline & - Behavioral Effects & $6 \%$ & $2 \%$ & $8 \%$ & $11 \%$ & $20 \%$ \\
\hline & - Speech Interference & $3 \%$ & $2 \%$ & $13 \%$ & $13 \%$ & $15 \%$ \\
\hline & - Hypertension & $16 \%$ & $7 \%$ & $10 \%$ & $17 \%$ & $13 \%$ \\
\hline & - Fatigue & $15 \%$ & $11 \%$ & - & - & $5 \%$ \\
\hline & - Concentration Loss & $5 \%$ & $7 \%$ & $12 \%$ & $13 \%$ & $12 \%$ \\
\hline & - Sleep disturbances & $7 \%$ & $12 \%$ & $16 \%$ & $17 \%$ & - \\
\hline
\end{tabular}




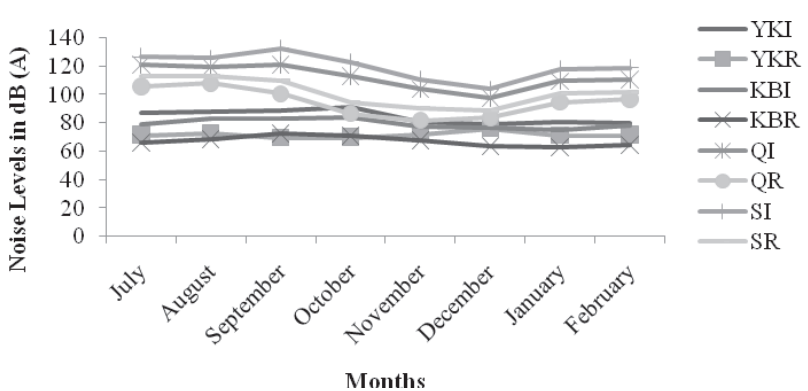

Fig. 6. Average monthly noise levels at all monitoring sites.

are 2 to 4 times elevated over the NAAQS (4 ppm) limit. The elevated $\mathrm{CO}$ emissions can be linked to incomplete combustion and directly related to traffic flow volume coupled with idle emissions due to traffic jams. The values are consistent with the past record, where $\mathrm{CO}$ concentration was recorded to be in the range of 4-12 ppm [12], which not only exceeded the standards.

Monthly mean TSP concentrations at all monitoring sites (Fig. 5) showed highest average concentration of TSP $\left(2999 \mu \mathrm{g} / \mathrm{m}^{3}\right)$ at YKI in November 2016, while the lowest was measured in August 2015 at QR $\left(68 \mu \mathrm{g} / \mathrm{m}^{3}\right)$. The overall average concentrations of TSP over the recorded monitoring period were $1046 \pm 954.318,815 \pm 542.940,809 \pm 607.357,622 \pm 431.903$, $906 \pm 244.330, \quad 746 \pm 166.207, \quad 1035 \pm 253.539, \quad$ and $785 \pm 272.011 \mu \mathrm{g} / \mathrm{m}^{3}$ at selected sites, i.e., YKI, YKR, KBI, KBR,QI, QR, SI, and SR respectively, exceeding NAAQS $\left(500 \mu \mathrm{g} / \mathrm{m}^{3}\right)$. Earlier studies reported maximum (1hr) TSP at YKI (i.e., $996 \mu \mathrm{g} / \mathrm{m}^{3}$ ) [12]. The higher levels of TSP may be due to the ongoing construction phase of orange line train at YKI and KBI, while at QI and SI the higher levels of TSP may be attributed to the construction phase of signal-free Jail Road.

Monitoring of air quality at Qartaba chowk, Shadman chowk, Fawara chowk, and Liberty in Lahore was carried out as a part of the EIA study that reported $\mathrm{SO}_{2}, \mathrm{NO}$, and $\mathrm{CO}$ levels to be within prescribed limits, while PM was higher than the standard, while at Qartaba chowk the situation was particularly critical [26]. At YKI there is more traffic congestion and heavy traffic than KBI, and also there are many open fields at KBI, which may be the reason behind low pollution levels. The monitored residential area (YKR) was downwind of YKI, whereas KBR was opposite the wind direction at the intersection. This is also a reason that YKR was comparatively more polluted than KBR. Due to their demographic status, these junctions represent higher traffic volumes on roads. QI and SI are the busiest commercial areas of Lahore. These areas have colleges, schools, restaurants, shops, hospitals, banks, and the popular Jilani Park. Temple Road and GOR-1 are the residential areas of Lahore near QI and SI, respectively. These are the lush green areas with grounds, parks, and clean and wide roads.

The highest noise level was measured at SI (133 dBA) in September 2015 while lowest was at KBR (63.1 dBA) in January 2016 (Fig. 6). The average noise levels throughout the monitoring cycle were $84.68 \pm 4.8798$, $71.8 \pm 1.9715, \quad 79.6 \pm 3.1234, \quad 67.2 \pm 3.4318, \quad 112.2 \pm 7.9237$, $95 \pm 15.4081,120.1 \pm 12.2957$, and $101.7 \pm 9.1652 \mathrm{~dB}$ at YKI, YKR, KBI, KBR, QI, QR, SI, and SR, respectively, in contrast to $85.5 \mathrm{~dB}$ as reported earlier at YKI [12]. Earlier highest noise levels (91-121 dB) were measured
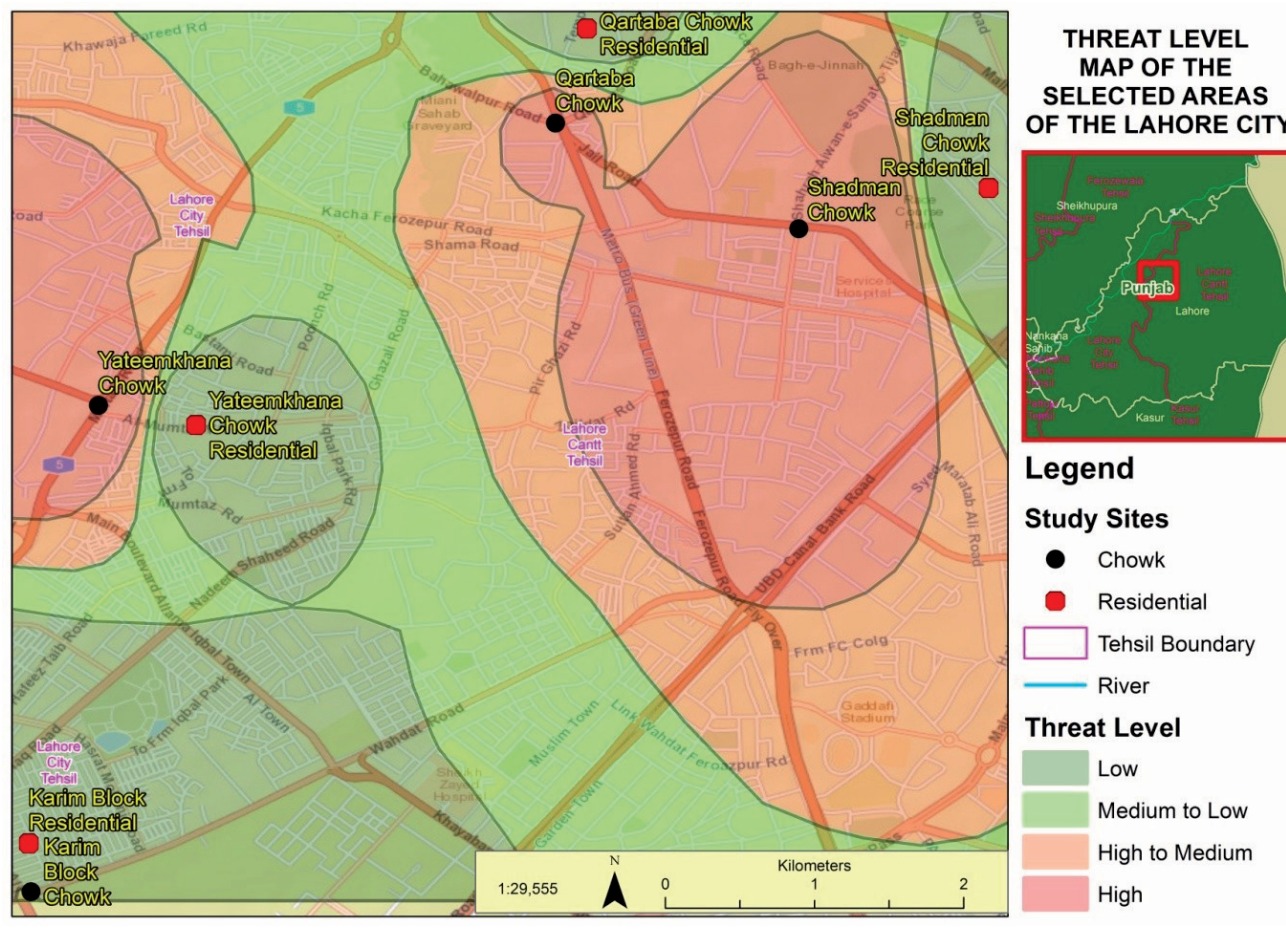

Fig. 7. Threat level map of the study areas of Lahore City. 
in major areas along the walled city and the inhabitants suffered from various related ailments [27].

India is also facing pollution problems as revealed by the results of a study conducted in Delhi for $\mathrm{NO}_{2}$ and $\mathrm{PM}_{2.5}$ monitoring. The mean of hourly $\mathrm{NO}_{2}$ concentrations was found to be $7.5 \%$ times higher than WHO standard value, while PM2.5 concentrations were found to be $25 \%$ higher than standard value, which indicate a high pollution burden [28].

In Delhi and Beijing trace gases and particulate matter were monitored from 8 and 12 measuring sites, respectively. The annual average of $\mathrm{PM}_{2.5}, \mathrm{PM}_{10}, \mathrm{O}_{3}$, $\mathrm{NO}_{2}$, and $\mathrm{CO}$ over Delhi was, respectively, $146.5 \mu \mathrm{g} / \mathrm{m}^{3}$, $264.3 \mu \mathrm{g} / \mathrm{m}^{3}, 24.7 \mu \mathrm{g} / \mathrm{m}^{3}, 19.8 \mu \mathrm{g} / \mathrm{m}^{3}$, and $1.73 \mathrm{mg} / \mathrm{m}^{3}$, and over Beijing $85.3 \mu \mathrm{g} / \mathrm{m}^{3}, 112.8 \mu \mathrm{g} / \mathrm{m}^{3}, 58.7 \mu \mathrm{g} / \mathrm{m}^{3}$, $53.4 \mu \mathrm{g} / \mathrm{m}^{3}$, and $1.4 \mathrm{mg} / \mathrm{m}^{3}$, respectively [29].

\section{Results of Questionnaire Survey; Health Impacts}

Health effects due to high noise levels were reported during the survey. Hearing impairment was experienced by $6 \%, 4 \%, 4 \%$, and $8 \%$ of respondents at YKR, KBR, QI, and SI, respectively, while in traffic wardens this percentage was higher $(13 \%)$. Other health problems related to high noise levels (headaches, depression, stress, and hypertension) were also identified during the study.

Health issues experienced by respondents due to air and noise pollution at area of interest (AOI) are given in Table 1. These results are consistent with literature, which reports incidences of hypertension and cardiovascular and ischemic heart diseases due to significant exposure to traffic noise [20,30], with higher occurrences among residents living in close proximity to a motorway [21].

A correlation test was applied in order to ascertain the relationships among pollutants. Pearson correlation was significant and showed the strongest association of NO and CO. Similarly, the correlation between TSP and $\mathrm{NO}$ and TSP and CO was also significant. Concentrations of CO and TSP increased due to high traffic flow, high temperature and humidity, and decreased wind speed. Moreover, association was also significant for air and noise pollution.

The selected intersections are heavy traffic spots due to the presence of educational institutions and the prevalence of commercial activities. In order to provide an explicit picture of the elevated concentrations of the gaseous pollutants $\left(\mathrm{SO}_{2}, \mathrm{NO}, \mathrm{CO}\right)$, TSP and noise levels, we utilized GIS to generate threat level maps of the AOIs. Spatial distribution of the pollutants is exhibited in Fig. 7.

\section{Conclusion}

The present study concludes that elevated levels of NO, CO, and TSP are prevalent in major areas of
Lahore. The general public is suffering from adverse effects of air and noise pollution, and long-term exposure poses a major risk to the population due to increasing traffic load and unchecked emissions. There is an urgent need to adopt air quality management strategies for improving air quality of urban centers. Public awareness programs regarding the use of a public transport system, strict implementation of issuance of fitness certificates for vehicles, and use of cleaner fuels need to be promoted to reduce vehicular emissions.

\section{Acknowledgements}

The authors would like to thank Kinnaird College for Women, Lahore for providing complete research facilities and GIS analyst, WWF for providing assistance in GIS mapping.

\section{Conflict of Interest}

The authors declare no conflict of interest.

\section{References}

1. WAHEED S., RAHMAN A., KHALID N., AHMAD S. Assessment of air quality of two metropolitan cities in Pakistan: Elemental analysis using INAA and AAS. Radiochimica Acta. 94, 161, 2006.

2. WHO (World Health Organization). Ambient air quality and health. Fact sheet N 313. WHO media Centre. Available at: http://www.who.int/mediacentre/factsheets/fs313/e n/. 2014.

3. CORREIA A. W., POPE III A. C., DOCKERY W. D., WANG Y, EZZATI M., DOMINICI F. The effect of air pollution control on life expectancy in the United States: an analysis of 545 US counties for the period 2000 to 2007. Epidemiology. 24 (1), 23, 2013.

4. LOOMIS D., GROSSE Y., LAUBY-SECRETAN B., GHISSASSI E. F., BOUVARD V., BENBRAHIMTALLAA L., GUHA N., BAAN R., MATTOCK H; STRAIF K. The carcinogenicity of outdoor air pollution. Lancet Oncol. 14, (13), 1262, 2013.

5. POPE III C. A., EZZATI M., DOCKERY W. D. Fine particulate air pollution and life expectancy in the United States .N. Engl. J. Med. 360 (4), 376, 2009.

6. HEI International Scientific Oversight Committee. Outdoor air pollution and health in the developing countries of Asia: A comprehensive review. Special Report 18. Health Effects Institute, Boston, MA. 2010.

7. HOPKE P.K., COHEN D.D., BEGUM A.B., BISWAS K.S., NI B., PANDIT G.G., SANTOSO M., CHUNG Y.S., DAVY P., MARKWITZ A. Urban air quality in the Asian region. Sci. Total Enviro. 404 (1), 103, 2008.

8. MAJID H., MADL P., ALAM K. Ambient air quality with emphasis on roadside junctions in metropolitan cities of Pakistan and its potential health effects. The Health 3 (3), 79, 2012.

9. Bureau of Statistics. Punjab Development Statistics. Lahore: Government of Punjab. 2015. 
10. JICA Consultants. The Project for Lahore Urban Transport Master Plan in the Islamic Republic of Pakistan. Lahore: Almec Corporation. 2012.

11. RASHEED A., ANEJA V.P., AIYYER A., RAfiQUE U. Measurements and analysis of air quality in Islamabad, Pakistan. Earth's Future. 2, 303, 2014.

12. GHAURI B., LODHI A., MANSHA M. Development of baseline (air quality) data in Pakistan. Environ Monit Asses. 127 (1-3), 237, 2007.

13. WAHEED S., RAHMAN A. DAUD M. Air quality evaluation of some industrial cities of Pakistan using INAA and AAS. Radiochimica Acta. 93, 487, 2005.

14. HASHMI D.R., SHAIKH G.H., USMANI T.H. Ambient air quality at Port Qasim in Karachi city. J Chem Soc of Pak. 27, 575, 2005a.

15. HASHMI D.R., SHAIKH G.H., USMANI T.H. Air quality in the atmosphere of Karachi city - an overview. J Chem Soc of Pak. 27, 6, 2005b.

16. Pak-EPA/JICA. 3 Cities Investigation of Air and Water Quality (Lahore, Rawalpindi \& Islamabad). JICA-PakEPA, June 2001.

17. Pak-EPA/JICA. Measurement of $\mathrm{NO}_{2}$ Concentration in Ambient Air in Major Cities of Pakistan Using Diffusion Samplers. 2006.

18. BISWAS K., GHAURI B., HUSAIN L. Gaseous and aerosol pollutants during fog and clear episodes in South Asian urban atmosphere. Atmos Environ. 42 (33), 7775, 2008.

19. ASLAM M.J., ASLAM M.A., BATOOL A. Effect of noise pollution on hearing of public transport drivers in Lahore city. Pak J Med Sci. 24, 142, 2008.

20. WHO (World Health Organization). Burden of Disease from Environmental Noise. Quantification of Healthy Life Years Lost in Europe. World Health Organization: Copenhagen, Denmark. 2011.
21. SHEPHERD D., DIRKS K., WELCH D., MCBRIDE D., LANDON J. The Covariance between Air Pollution Annoyance and Noise Annoyance, and Its Relationship with Health-Related Quality of Life. Int. J. Environ. Res. Public Health. 13, 792, 2016.

22. BABISCH W. Cardiovascular effects of noise. Noise Health. 13, 201, 2011.

23. VAN KEMPEN E., BABISCH W. The quantitative relationship between road traffic noise and hypertension: A meta-analysis. J. Hypertens. 30, 1075, 2012.

24. HAMMERSEN F., NIEMANN H., HOEBEL J. Environmental Noise Annoyance and Mental Health in Adults: Findings from the Cross-Sectional German Health Update (GEDA) Study 2012. Int. J. Environ. Res. Public Health. 13 (10), 954, 2016.

25. SGS Pakistan. Monitoring report Asian Consulting Engineers Lahore. 2015.

26. Asian Consulting Engineers. Construction of Signal Free Coridors Jail Road and Main Boulevard Gulberg Lahore, Environmental Impact Assessment (EIA) Report, Lahore Development Authority. 2015.

27. YOUNES I., GHAFFAR A. Spatial pattern of noise pollution in Lahore city (2011). AJSSH. 1 (2), 53, 2012.

28. ZHENG S., SINGH R.P., WU Y. WU C. A Comparison of Trace Gases and Particulate Matter over Beijing (China) and Delhi (India). Water Air Soil Pollut. 228 (5), 181, 2017.

29. GULIA S., NAGENDRA S.S., KHARE, M. Extreme events of reactive ambient air pollutants and their distribution pattern at urban hotspots. Aerosol and Air Qual Res. 17, (2), 3945, 2017.

30. BASNER M., BABISCH W., DAVIS A., BRINK M., CLARK C., JANSSEN S., STANSFELD S. Auditory and non-auditory effects of noise on health. Lancet. 383, 1325, 2014. 
